$\begin{array}{lll}\text { KULTURA } & \begin{array}{l}\text { POLSKA A KADEMIA NAUK } \\ \text { KOMITET SOCJOLOGII }\end{array} & \text { ISSN 0023-5172 } \\ \text { i } & \begin{array}{l}\text { INSTYTUT STUDIÓW POLITYCZNYCH } \\ \text { SPOLECZENSTWO }\end{array} & \\ 2018, \text { nr } 1 & \text { GENEALOGIA PODZIAEÓW }\end{array}$

MARCIN KOTRAS

Uniwersytet Łódzki

\title{
NARRACJE I STRATEGIE ARGUMENTACYJNE W DYSKURSIE IV RP JAKO NARZĘDZIA WYZNACZANIA GRANIC WSPÓLNOT W POLSKIM SPOŁECZEŃSTWIE
}

\section{PRZEBIEG TRANSFORMACJI USTROJOWEJ W POLSCE A DYSKURS IV RP}

Zmiana władzy w Polsce po wyborach 2015 roku jest przedstawiana przez zwycięski obóz - i związane z nim media - jako wygrana reprezentantów „zwykłych Polek i Polaków”, dotychczas wykluczonych z podziału potransformacyjnych korzyści, a także jako porażka starych elit („elit III RP”), które swoje pozycje uzyskały za sprawą sposobu, w jaki dokonała się zmiana transformacyjna. W tym samym czasie $\mathrm{w}$ dyskursie publicznym upowszechniła się teza o wewnętrznym podziale społeczeństwa polskiego na zantagonizowane grupy, z których jedna wspiera obóz „dobrej zmiany”, a druga próbuje się mu przeciwstawić. I choć to stwierdzenie znacząco upraszcza logikę podziałów w polskim społeczeństwie, to ma zasadniczy wpływ na sposób kształtowania się różnego rodzaju dyskursów odpowiedzialnych za formowanie się pęknięć w społeczeństwie, w tym dyskursu IV RP.

Podziały społeczne w obszarze dyskursu pozwala opisywać choćby koncepcja Jeffreya Alexandra (2010), który posługuje się kategorią dyskursu binarnego (polaryzacyjnego). W myśl jej założeń strony zaangażowane w opis i definiowanie rzeczywistości społecznej przy użyciu wybranych kodów kulturowych tworzą własne środowiska symboliczne. Rezultatem dyskursu obywatelskiego może być, zdaniem Alexandra, podział wspólnoty na wykluczonych (niezasługujących na przynależność do niej) i włączonych (spełniających zdefiniowane 
kryteria członka wspólnoty), przy czym przeciwnicy wzajemnie oskarżają się o to, że rywale posługują się kodem ucisku (niedemokratycznym), sobie zaś przypisują kod wolności (demokratyczny). Dyskurs IV RP, jego retoryka, sprzyja wykluczaniu wybranych grup społecznych i tworzeniu ekskluzywnych wspólnot, w tym wspólnoty narodowej.

Kampania wyborcza 2015 roku dowiodła skuteczności tego rodzaju retoryki. Ugrupowania, które z niej korzystały, poparła łącznie ponad połowa obywateli, przy najwyższym poparciu dla Prawa i Sprawiedliwości. Zwraca na to uwagę Paweł Ścigaj w dyskusji opublikowanej na łamach „Władzy Sądzenia” (zob. Kurczewska, Cześnik, Pluciński, Ścigaj 2016). Jego zdaniem, zwycięzcy w otwarty i bardzo krytyczny sposób odrzucili ponad ćwierć wieku transformacji, zaproponowali wyborcom zerwanie ciągłości (politycznej, instytucjonalnej, kulturowej) z III RP i rozpoczęcie nowego rozdziału w historii Polski. To, czy spór o transformację jest realny, czy jedynie wykreowany na użytek zaangażowanych stron, $w$ tym przypadku miało znaczenie drugorzędne. Istotne jest to, że stał się on częścią rywalizacji o kontrolę nad sferą znaczeń.

Formowania się dyskursu IV RP nie należy jednak wiązać wyłącznie (i bezpośrednio) ze zwycięstwem Prawa i Sprawiedliwości w wyborach w 2015 roku czy wcześniejszym sukcesem tej partii w 2005 roku. Jest on elementem czegoś, co można nazwać programem politycznym mającym umożliwić trwałe przejęcie władzy przez PiS (i powiązane z nim ugrupowania i środowiska) za sprawą rekonstrukcji potransformacyjnego ładu i zakwestionowania dotychczasowej logiki modernizacji. Te dwa postulaty mają znaczenie podstawowe $-\mathrm{w}$ dyskursie IV RP powstanie III RP oraz sposób transformowania kraju uznawane są za przyczyny stopniowego upadku państwa, czemu towarzyszy marginalizacja wielu grup społecznych, gdyż złamanie sprawiedliwych reguł gry nastąpiło już przy Okrągłym Stole. W analizie należy zatem cofnąć się do początków transformacji w Polsce.

W roku 1989 mimo fali społecznego entuzjazmu towarzyszącej wówczas zmianie ustroju trudno było uznać zaproponowany społeczeństwu scenariusz zmian za wynik kompromisu wypracowanego przez obywateli w jakiejś ogólnonarodowej dyskusji uwzględniającej racje i interesy różnych grup. Przekonanie elit symbolicznych (części polityków, dziennikarzy, intelektualistów) o tym, że zawarta ze społeczeństwem umowa społeczna była powszechnie aprobowana, mogło opierać się na tym, iż środowiska odpowiedzialne za scenariusz transformacyjnych zmian miały legitymację społeczną. Osiągnięcie statusu rządzących odbyło się w wyniku wolnych wyborów, a więc przy przynajmniej częściowej społecznej akceptacji.

Jednak już w okresie „pookrągłostołowym” w społeczeństwie polskim pojawia się jedna $z$ istotniejszych linii granicznych. Po jednej stronie znalazły się „oświecone elity”, wyznaczające właściwą ścieżkę transformacji i podążające nią, a dla pozostałej części społeczeństwa wyznaczające cele modernizacyjne, po drugiej zaś - ci, którzy mieli zaadaptować się do zmieniającego się świata. 
Ci drudzy nie stanowili homogenicznego zbioru. Istotna część tej grupy Polaków zinternalizowała katalog cech, jakie — zdaniem elit — powinien posiadać nowoczesny Europejczyk i ruszyła wyznaczoną przez planistów transformacji ścieżką modernizacji i wzrostu. Byli to najczęściej ci, którzy zaakceptowali dominację swoistej ideologii „radzenia sobie” i wdrożyli w życie kierowane do nich zalecenia o konieczności „wzięcia losu w swoje własne ręce”, włączenia się do gry ekonomicznej polegającej na zwiększaniu swoich kompetencji i konkurencyjności na rynku pracy. Trudno jednoznacznie wskazać miejsce tej zróżnicowanej grupy w strukturze społecznej. W opisach społeczeństwa polskiego wskazywano ich jako zalążek potransformacyjnej klasy średniej. Po drugiej stronie omawianej linii granicznej obok tej grupy "poprawnie zaadaptowanych” znaleźli się również ci, którzy zostali zepchnięci do kategorii „nieoświeconych mas", hamulcowych zmian, którzy nie tylko nie byli zdolni sprostać nowym wyzwaniom i warunkom społecznym czy kulturowym, ale też nie pasowali do wzoru nowego obywatela. Co więcej, dla tej grupy nie tylko cele zmian społecznych były niejasne, ale także wyłaniający się ład społeczny był odbierany przez nich jako niezgodny z oczekiwaniami. Z czasem stali się oni odrębną grupą, pozostającą na uboczu dokonujących się przemian, ale jednocześnie zyskali status istotnej grupy docelowej, potencjalnego elektoratu dla tych środowisk i ugrupowań, które kontestowały zarówno porozumienia „okrągłostołowe”, jak i późniejszy scenariusz przemian.

Jakub Majmurek (2013) stawia tezę, że lud nie spełnił wówczas oczekiwań elit i w ich opinii w niewłaściwy sposób korzystał ze swojej wolności — miał zły gust, banalną dietę, niewygórowane potrzeby kulturowe. Konieczne zatem stały się działania dyscyplinujące i mechanizmy socjalizacyjne kierowane do tych, którzy nie potrafili sprostać logice przemian. W konsekwencji sprawowanie władzy w transformującej się Polsce miało charakter „zarządzania wstydem”. Ten typ działania to, zdaniem Majmurka, „pedagogika wstydu” " podejmowana z pozycji planistów transformacji w stosunku do krytykowanych (niekiedy wyszydzanych i zawstydzanych) mas. Ludzie ci byli określani jako: „ciemnogród”, „moherowe berety”, „katole”, „prowincja”. Relacja między „oświeconymi elitami” a "prowincjonalnym ludem” wpłynęła na logikę polskich przemian, dając początek „polskim swarom” (zob. Śpiewak 2005), a w konsekwencji podziałom społecznym, które obok czynników ekonomicznych opierały się na kwestiach kulturowych i symbolicznych ${ }^{2}$.

${ }^{1}$ Tym terminem posługuje się również prawicowa, konserwatywna prasa, ale w publikowanych tam tekstach nazywa się tak wszelkie komentarze odbierane jako próby wpędzenia Polaków w poczucie winy, wywołania u nich myślenia o sobie jako o gorszych. Określa się tam w ten sposób również te elementy polityki historycznej i kulturowej, które odnoszą się do konieczności przyjmowania przez Polaków części winy za zbrodnie popełnione w czasie drugiej wojny światowej (np. na ludności żydowskiej).

2 Dychotomicznie postrzegany podział na uprzywilejowane elity i pozbawione beneficjów masy pojawiała się między innymi w dotyczących stanu współczesnej kultury krytycznych rozważaniach 
Problemem rozłamów społecznych i relacji międzypartyjnych zajmowali się między innym dwaj badacze o liberalnych poglądach - Seymour Martin Lipset i Stein Rokkan. Ich makrohistoryczne badania odnosiły się do zachodnich systemów podlegających procesowi demokratyzacji (Lipset 1995). Opisywana przez nich logika rozłamów (social cleavages) wynikała $z$ istniejących wewnątrz społeczeństwa dychotomii, z których jedną z najważniejszych była relacja centrum-peryferie. Z jednej strony występowały w nim elity, najczęściej kojarzone $\mathrm{z}$ ośrodkami wielkomiejskimi, a $\mathrm{z}$ drugiej strony obywatele żyjący $\mathrm{z}$ dala od metropolii, na prowincji. W pewnym stopniu przypomina to rozłam na „elity” i „zwykłych ludzi” w Polsce, ale w modelu Lipseta i Rokkana rezultatem takiego podziału było pojawianie się partii regionalnych odwołujących się do lokalnego patriotyzmu (czy nacjonalizmu) bądź stronnictw separatystycznych. Stawały one w kontrze do mainstreamowego ugrupowania występującego $z$ poziomu centrum. Konflikt zatem opierał się na relacji między wspieraną przez systemy biurokratyczne elitą reprezentującą kulturę narodową a mniejszościami odwołującymi się do różnej formy kulturowych partykularyzmów. Jeśli odniesiemy się do retoryki środowisk odrzucających III RP, to różnica między modelem opisywanym przez amerykańskich badaczy a podziałami w Polsce dotyczy tego, że „Wstający z kolan zwykli Polacy”, „odzyskujący godność” nie dążą do konfrontacji między partykularyzmami i mainstreamem, ale w zasadzie do tego, aby stać się nowym mainstreamem dzięki rekonstrukcji społeczno-kulturowego ładu. W dychotomii centrum-peryferie rola centrum przypisana została brukselskim elitom, a peryferie to grupy i środowiska polityczne dążące do ugruntowania „naszej”, narodowej godności ${ }^{3}$.

Kształt podziałów społecznych jest ściśle związany z formułą dyskursu publicznego, co uzasadnia potrzebę namysłu nad „programem IV Rzeczypospolitej" (niezależnie od tego, czy realnie on istnieje), a w szczególności nad dyskursem IV RP, którego uczestnicy podzielają pewien repertuar przekonań spo-

amerykańskiego historyka Christophera Lascha (1997, s. 37), który twierdził, że bieg historii kieruje nas w stronę społeczeństwa dwuklasowego, a „[...] uprzywilejowana garstka monopolizuje korzyści płynące z pieniędzy, wykształcenia i władzy". Elity przy tym stopniowo uniezależniają się od reszty społeczeństwa, rezygnując z usług publicznych i przenosząc się do sektora prywatnego, na przykład w zakresie usług medycznych czy edukacyjnych. Proces ten znalazł odzwierciedlenie $\mathrm{w}$ formule debat publicznych, które stały się domeną tzw. klas mówiących, przez co zyskały status zamkniętych, specjalistycznych, protekcjonalnych i elitarnych właśnie (Lasch 1997, s. 85). Uwagi te, choć dotyczą społeczeństwa amerykańskiego i wypowiadane były przez krytyka liberalizmu, $\mathrm{w}$ istocie współbrzmią z retoryką środowisk krytykujących ład po Okrągłym Stole i III RP.

${ }^{3} \mathrm{~W}$ interesujący sposób problematyka podziałów społecznych została opracowana przez Mirosławę Grabowską (2004), która posługując się kategorią tożsamości i odnosząc ją do postaw, zachowań oraz przynależności politycznych, wskazała na główną oś podziału między postkomunistami i antykomunistami. Jej zdaniem, był to podział na lata organizujący dynamikę procesów politycznych skutkujących podziałami wewnątrz systemu partyjnego i w społeczeństwie. Choć trudno mówić o jego całkowitej dezaktualizacji, to dzisiejsze linie i dynamika podziałów dotyczą nieco innych kategorii. 
łeczno-kulturowych (van Dijk 2001, s. 26). Należy więc podjąć analizę narracji i strategii argumentacyjnych, których konsekwentne wykorzystywanie w dyskursie sprzyja dynamice pogłębiania się zróżnicowań a społeczeństwie.

Narracja może być rozumiana jako: sposób komunikowania, opowieść o świecie, myślenie o świecie, opowiadanie świata i wyjaśnianie rzeczywistości (Jakubowska-Branicka 2013, s. 37-39). Jest to: „uporządkowany ciąg opisowy, który ma być zapisem pewnych wydarzeń [...] to opowieści skonstruowane, które stanowią próbę wyjaśnienia sposobów funkcjonowania świata. Dostarczają nam struktur rozumienia i reguł odniesienia dotyczących sposobu konstrukcji świata społecznego, udzielając tym samym odpowiedzi na pytanie: jak żyć" (Barker 2005, s. 32). Odnosi się zarówno do teraźniejszości, jak i do przeszłości (Burszta 2013, s. 245-246; Wasilewski, 2012, s. 25). W narracji są wykorzystywane różne strategie argumentacyjne ${ }^{4}$, które odnoszą się do wybranych segmentów systemu społecznego i ekonomicznego oraz do rezerwuarów ideologicznych w taki sposób, aby za pomocą odpowiednich środków retorycznych tworzonym opisom rzeczywistości nadać sens wspierający tezy nadawcy (Messyasz 2013, s. 123).

W Polsce narracja odnosząca się do podziału na elity i masy stała się kluczowym elementem strategii argumentacyjnych środowisk prawicowych i konserwatywnych ${ }^{5}$, które wśród wyborczych haseł zamieszczały te o „przywróceniu godności zwykłym Polakom”, co w dużej mierze przyczyniło się do ich pełnego zwycięstwa wyborczego w 2015 roku. Jednocześnie celem politycznym tych ugrupowań stały się grupy społeczne, które charakteryzowano na przykład za pomocą figury homo sovieticus. „Małomiasteczkowa, katolicka Polska”, zawstydzana dotychczas przez wielkomiejskie elity stała się kluczową częścią elektoratu dla środowisk politycznych kontestujących Okrągły Stół i ukształtowany w jego wyniku ład. Odwołując się do koncepcji Petera Sloterdijka (2011), można powiedzieć, że środowiska polityczne krytykujące potransformacyjny porządek zamieniły społeczny gniew zawiedzonych transformacją $\mathrm{w}$ kapitał polityczny służący zdobyciu poparcia wyborczego.

Warto dodać, że $\mathrm{w}$ dyskursie dotyczącym transformacji zmianie uległy również granice wyznaczające główny obszar debaty publicznej — wyłączone zostały odwołania do tradycji socjalistycznej i lewicowej (Drozda 2015, s. 9). Partie wywodzące się z poprzedniego systemu w sposób w zasadzie bezkonfliktowy

${ }^{4}$ Strategie argumentacyjne rozumiane są tu zgodnie z założeniami krytycznej analizy dyskursu Teuna van Dijka (2006). Jego zdaniem, zastosowanie odpowiednich strategii argumentacyjnych w dyskursie służy budowaniu dominacji jednych grup nad innymi, umożliwia zniekształcanie rzeczywistości (zgodnie z intencją nadawcy strategii, z postulowaną przez niego „wersją” wydarzeń), pozwala narzucić określoną wizję świata (w którym możliwe są na przykład wykluczenie i dyskryminacja), która stać się może uprzywilejowaną w procesie definiowania rzeczywistości politycznej.

${ }^{5}$ Kategorii tych używam w znaczeniu, jakie przypisuje się im przy opisie sceny politycznej $\mathrm{w}$ Polsce, czyli raczej jako porządkujących etykiet, a nie w sensie definicyjnym przyjmowanym w naukach społecznych i politycznych. 
przystąpiły do realizacji planu transformacji politycznej i gospodarczej, co mogło być działaniem uwiarygadniającym lewicowe (postpezetpeerowskie) środowisko w ramach nowego ładu politycznego. W konsekwencji nastąpiła między innymi zmiana retoryki takich ugrupowań jak Sojusz Lewicy Demokratycznej. Natomiast lewicowy dyskurs - ten odwołujący się do tradycji socjalistycznej, robotniczej czy syndykalistycznej — przeniósł się bądź do akademii, bądź do wyraźnie sprofilowanych czasopism i pozostaje bez wyraźnego wpływu na problematyzację transformacyjnej zmiany. Sporadycznie pojawiają się jedynie te postulaty, które wynikają z przemian kulturowych i dotyczą tzw. wartości postmaterialnych i kwestii światopoglądowych. Lewicowe partie i inicjatywy traktuje się bądź jako kontynuację rozwiązań politycznych z poprzedniego systemu, bądź przypisuje się im instrumentalne cele polityczne polegające głównie na płynnym przejściu do nowego ładu politycznego i budowaniu własnej pozycji ekonomicznej w nowych warunkach. Krytykuje się również te lewicowe treści, które odnoszą się do kwestii kulturowych i światopoglądowych, prezentując je jako zagrożenie niosące zmiany społeczne dotyczące na przykład praw mniejszości seksualnych czy postulatów ograniczenia roli Kościoła katolickiego w sferze publicznej. Zakwalifikowanie jakiejś organizacji jako lewicowej zwykle bywa wynikiem etykietowania.

\section{MEDIA I DZIENNIKARZE JAKO WSPÓŁTWÓRCY PODZIAŁÓW SPOŁECZNYCH}

Chociaż media dotyka dziś kryzys uwagi, nie znaczy to, że rola dziennikarzy i publicystów jest nieistotna, zwłaszcza w zakresie dostarczania „dobrych opowieści", które redefiniują i wyjaśniają znaczenie procesów politycznych czy ekonomicznych. Najważniejsze jest jednak to, że publikujący w opiniotwórczych tygodnikach już dawno przedefiniowali pełnioną przez siebie rolę. Mamy dziś do czynienia nie tyle $z$ „piszącymi na łamach”, którzy przygotowują teksty publikowane $\mathrm{w}$ czasopismach, ale $\mathrm{z}$ medialnymi personami, które kształtują środowisko informacyjne odbiorcy, dostarczając mu właściwych (z ich punktu widzenia) kategorii i pojęć służących do definiowania rzeczywistości. Wykorzystują do tego kanały komunikacyjne nowych i starych mediów, ale najpełniejszą formą dziennikarskiej wypowiedzi pozostają artykuły zamieszczane w tygodnikach. Pozwalają bowiem na rozbudowaną argumentację, przytaczanie wielu przykładów, zawierają swoistą „linią programową" autora, która multiplikuje się w innych wypowiedziach, komunikatach czy internetowych postach.

Zaangażowanie mediów w spór dotyczący oceny transformacji i funkcjonowania III RP wydaje się czymś naturalnym i odpowiada zasadzie pluralizmu politycznego mediów. Media, ich reprezentanci, nie tylko opowiadają się po jednej ze stron sporów, ale wprost włączają się $\mathrm{w}$ akcje i przedsięwzięcia polityczne. Nie jest to w żadnym wypadku polska specyfika, lecz sposób funkcjonowania w wielu systemach politycznych (Hallin, Mancini 2004, s. 24-27). W przypadku sporu toczącego się obecnie w Polsce podziały w obrębie elit mają charakter 
światopoglądowy, a nie funkcjonalny. Skuteczność elit, zwłaszcza zaś elit władzy, rośnie wtedy — jak twierdzi James Meisel (1980) — kiedy charakteryzuje je: świadomość grupowych celów, wewnętrzna spójność i chęć do wspólnego działania. Obecnie warunki te w szczególności spełniają politycy będący reprezentantami „obozu dobrej zmiany”, a w środowisku medialnym - grupa dziennikarzy wywodzących się ze środowiska tzw. niepokornych, czyli prawicowych i konserwatywnych publicystów związanych z tytułami, które mają krytyczny stosunek do III RP. Mimo istnienia pewnych różnic grupę tę charakteryzuje duża spójność przekazu i świadomość wspólnego celu, jakim jest delegitymizacja dotychczasowego ładu instytucjonalnego.

Dziennikarzy i publicystów związanych z głównymi nadawcami medialnymi, tytułami prasowymi, kanałami telewizyjnymi, portalami społecznościowymi należy uznać za przedstawicieli elity symbolicznej. To ważni aktorzy polityczni, mający wpływ na organizację dyskursu politycznego, problematyzowanie zjawisk i procesów istotnych dla funkcjonowania społeczeństwa, a w konsekwencji na formowanie się granic podziałów społecznych. Zasadna zatem wydaje się analiza używanych przez nich strategii argumentacyjnych, które konsekwentnie stosowane mogą służyć do konstruowania takich granic.

Analizę taką można ująć w ramy propozycji analitycznej Stanleya Fisha (2002), który posłużył się pojęciem w s pól not in terpretacyjnych. Odnosi się ono do grupy, złożonej z osób w podobny, niekiedy taki sam, sposób odczytujących i interpretujących komunikat. Jego znaczenie kształtuje się zatem wewnątrz wspólnoty (publiczności, odbiorców), a jego istnienie poza interpretacją grupy z punktu widzenia nadawcy i odbiorcy komunikatu jest w zasadzie nieistotne. Założenie o istnieniu takich wspólnot interpretacyjnych jest istotne nie tylko z punktu widzenia refleksji na temat odbiorcy komunikatu, ale też ze względu na chęć poznania, jak działa autor komunikatu — producent tekstu.

Interpretacja danego tekstu odwołuje się do zasobów kulturowych, którymi dysponuje wspólnota interpretacyjna. Znaczenie ma zatem społeczny i kulturowy kontekst, w jakim ona funkcjonuje. W przypadku in ter pret acji ad a ptacyjnej, która jest przedmiotem przedstawionej tu analizy, kluczowe stają się zasoby kulturowe czytelnika. Wiedza na temat przeszłości jest zapośredniczona interpretacyjnie - przeszłość staje się takim samym tekstem jak inne teksty kulturowe (Szahaj 1997) ${ }^{6}$. Wprowadzającemu określone strategie argumentacyjne zależy na tym, aby proponowana interpretacja skonwencjonalizo-

\footnotetext{
${ }^{6}$ Inny rodzaj interpretacji - interpretacja historyczna - uwzględnia złożone relacje polityczne, zachodzące w danym momencie procesy ekonomiczne, odnosi się do aktualnego kontekstu. Przede wszystkim jednak opiera się na dostępnej wiedzy na temat działania gospodarki, modernizacyjnych ścieżek, mechanizmów rynkowych. W myśl teorii reader-response criticism każda interpretacja bazująca na tekście (odnosząca się do przeszłości) ma charakter adaptacyjny, bo nie mamy żadnego bezpośredniego dostępu do kontekstu kulturowego, w którym opisywane wydarzenia miały miejsce. Zdaniem Stanleya Fisha, zwolennika tej teorii, nie istnieją żadne ograniczenia interpretacji, które same nie są rezultatem interpretacji.
} 
wała się i została zaakceptowana przez odbiorców jako „poprawna” opowieść dotycząca przeszłych wydarzeń.

Dyskurs rozumiany jako proces jest odpowiedzialny za tworzenie znaczeń, a tym samym dostarczenie określonej matrycy interpretacji przeszłych i teraźniejszych wydarzeń, ma wpływ na relacje władzy — związana z nim produkcja znaczeń każdorazowo odnosi się do określonego kontekstu, a tym samym może być wykorzystywana $\mathrm{w}$ procesie legitymizacji bądź odmowy prawomocności określonym instytucjom władzy. Strategie argumentacyjne używane w mediach przyczyniają się też do konstruowania bądź wzmacniania podziałów społecznych. Charakter współczesnych rozłamów w Polsce oraz ich logika każą zastanowić się nad źródłem tego zjawiska oraz jego konsekwencjami dla kształtu debaty publicznej.

Zamierzam tu przedstawić wyniki analizy, której celem jest wyodrębnienie i opis strategii argumentacyjnych stosowanych w polskich tygodnikach prawicowych i konserwatywnych. Czasopisma, z których pochodziły analizowane artykuły to najlepiej sprzedające się w Polsce konserwatywne/prawicowe tygodniki opinii: „WSieci” / „Sieci Prawdy” / „Sieci”7 (WS) i „Do Rzeczy” (DR), określane w tekście wspólnym mianem - „prasa/media IV RP”. Pierwsze ich numery ukazały się na rynku w październiku 2012 roku (WS) i w styczniu 2013 roku (DR). Jednak początków obu tych tytułów należy szukać wcześniej, w 2010 roku. Wtedy bowiem zaczął być wydawany prawicowy, konserwatywny tygodnik „Uważam Rze”, a w jego redakcji znaleźli się najbardziej uznani prawicowi publicyści i dziennikarze. Redaktorem naczelnym tej gazety został Paweł Lisicki, obecnie naczelny „Do Rzeczy”, a jego zastępcą Michał Karnowski, obecnie naczelny „Sieci”.

Analizowane artykuły pochodzą z lat 2012-2017. Obejmują zatem czas rządów koalicji Platformy Obywatelskiej-Polskiego Stronnictwa Ludowego oraz moment zmiany władzy i rządy Prawa i Sprawiedliwości oraz prezydenta Andrzeja Dudy. Miały dostarczyć spójnej egzemplifikacji tego, w jaki sposób prasa IV RP charakteryzowała i definiowała zarówno przeszłą, jak i zastaną rzeczywistość. Nie zastosowano założenia o tzw. czystości gatunkowej, nie miało zatem znaczenia to, czy były to teksty publicystyczne, opinie, stanowiska, reportaże, czy też krótkie felietony. Nie chodziło bowiem o sprawdzenie tego, jak wyglądają strategie argumentacyjne $\mathrm{w}$ określonym gatunku dziennikarskim, ale o potraktowanie tytułów w całości jako reprezentujących określone stanowisko polityczne i stosujących ustalone strategie argumentacyjne dotyczące transformacji. Kluczem doboru była zatem istotność tekstu i to, czy odnosił się on do transformacji ustrojowej. Podczas systematycznej i uważnej lektury tygodników były prowadzone notatki badawcze dotyczące problematyzowania transformacji ustrojowej i strategii nazywania podmiotów zbiorowych, takich jak

7 Tygodnik „wSieci” w wyniku przegrania procesu sądowego musiał zrezygnować ze swej dotychczasowej nazwy i zmienić ją na "Sieci Prawdy”, z czasem ponownie zmienionej na tytuł "Sieci”. 
„elity III RP”. Teksty prasowe opracowywano również przy użyciu programu NVivo 10, szukając między innymi słów-kluczy (np. „zwykli Polacy”, „transformacja”, „Okrągły Stół”, ,elity”, „lewica”, „konserwatyzm”, „naród”) i zwracając przy tym uwagę na kontekst i sposób ich użycia przez dziennikarza. Szczególną uwagę kierowano na tzw. sytuacje przełomu. Można mówić o dwóch takich wydarzeniach. Pierwszy to katastrofa smoleńska, pełniąca rolę mitu założycielskiego dla środowiska prasy IV RP (a także ogólnie dla obozu „dobrej zmiany"). Drugi to zwycięstwo kandydata PiS Andrzeja Dudy w wyborach prezydenckich w 2015 roku, w których pokonał on urzędującego prezydenta i kandydata popieranego przez PO - Bronisława Komorowskiego.

Zasadność zainteresowania przekazem mediów potwierdza ponadto kształt sceny politycznej po wyborach z 2015 roku. Zdobycie pełni władzy politycznej przez jedno ugrupowanie (co zdarzyło się po raz pierwszy po 1989 roku) zmieniło układ sił. Centrum decyzyjne przesunęło się poza instytucję parlamentu w stronę kierownictwa partii politycznej - Prawa i Sprawiedliwości. Sukces wyborczy tej partii i konsekwentne moderowanie tematów dyskursu politycznego nie byłyby możliwe, gdyby nie zaangażowanie wspierających to środowisko mediów.

Podczas analizy tekstów poszukiwano zabiegów retorycznych, które służyły definiowaniu różnic oraz były wykorzystywane w strategiach nazywania „drugiej strony” sporu — politycznych i medialnych oponentów. Szczególnie interesujące są $\mathrm{w}$ tym kontekście kategorie odnoszące się nie tyle do podmiotów indywidualnych, ile do podmiotów zbiorowych, takich jak elity czy lewica. $\mathrm{W}$ analizowanych tekstach szukano też odniesień polityczno-społecznych dotyczących przeciwstawnych grup: wygrani-przegrani transformacji, elita-zwykli ludzie, lewica-prawica. Ponadto zwracano uwagę na forsowanie w tekstach obrazu określonych tożsamości politycznych. Było to bowiem „szykowanie podłoża" pod praktyki dyskryminacyjne, przy czym powód owej dyskryminacji miał charakter arbitralny, zgodny ze strategia argumentacyjną nadawcy. W konsekwencji odbierano określonym grupom prawo do wypowiedzi - ze względu na niewłaściwe zachowanie w początkach transformacji, afiliację polityczną czy pozycję społeczną.

Dyskredytacja mogła mieć charakter identyfikacyjny poprzez przypisanie konkretnym grupom negatywnych kategorii, na przykład: „wojujące autorytety” (Semka 2013), „post-Polak” (Pawlicki 2016), „przemysł pogardy” (Cenckiewicz 2014), „lewactwo” (Nykiel 2013a, 2013b; Terlikowski, Terlikowska 2013; Ziemkiewicz 2015a). Mogła mieć również postać dyskredytacji ideologicznej, gdy wybrane doktryny i orientacje polityczne wskazano jako skompromitowane i zużyte, określając je jako: „liberalne”, „neoliberalne”, „lewicowe”, „lewackie”, „lewactwo”, „wyznawcy gender i multikulti”. Tego typu praktyki służą temu, by na trwałe wykluczyć drugą stronę z debaty publicznej, uczynić ją jej nieprawomocnym uczestnikiem, czyli po jednej stronie postawić tych, którzy posługują się prawomocnym dyskursem opartym na kodzie 
wolności, a po drugiej delegitymizowane grupy, posługujące się kodem niedemokratycznym.

Przedmiotem analizy były również te elementy strategii argumentacyjnych, które służyły ukierunkowaniu sporu. Próbowano ustalić: Jaki typ argumentacji można odnaleźć $\mathrm{w}$ analizowanych tygodnikach? Jakie cechy przypisuje się przeciwnikom politycznym? Do jakich archetypów odwołują się dziennikarze? Czy retoryka prasy IV RP nosi cechy retoryki populistycznej? Jaki jest sposób formatowania dyskursu, czyli jak definiuje się kontekst (sytuację).

\section{NARRACJA MEDIÓW IV RP — WYNIKI ANALIZY}

Media w celu budowania wspólnoty interpretacyjnej stosują określone strategie argumentacyjne, sięgając do rezerwuarów ideologicznych i wykorzystując różne formy opisu. Kreowane w mediach ,językowe inscenizacje” ukierunkowują interpretację kluczowych „spraw”, wydarzeń i procesów, a prezentacja tzw. dobrych historii ma to potwierdzić. W narracji mediów IV RP przedmiotem tych strategii są dotychczasowe przemiany w Polsce, opinie na temat obecnego stanu państwa oraz relacje między „elitami” i „zwykłymi ludźmi”. Dąży się do tego, aby członkowie wspólnoty mieli podobny stosunek do III RP (jako politycznej, instytucjonalnej i kulturowej całości) oraz do transformacji, która wpłynęła na jej kształt. Ma go umacniać podobna ocena wprowadzanych do dyskursu publicznego „spraw”, takich jak kryzys migracyjny w Europie i związany $z$ tym problem przyjmowania uchodźców w naszym kraju. Powinni również w podobny sposób postrzegać bieżące wydarzenia oraz swój wpływ na proces decyzyjny w polityce.

Posługiwanie się w prasie IV RP narracją o III Rzeczpospolitej jako państwie skompromitowanym wiąże się z określonym sposobem opisu i definiowania nie tylko instytucji, ale również wybranych grup społecznych. Nadawanie znaczeń takim kategoriom jak: „III RP”, „lewica/lewactwo”, „elity” czy „establishment”, „postkomuna”, ma charakter arbitralny. Nie chodzi o dotarcie do „prawdziwych” znaczeń tych kategorii, ale o to, żeby w tej swoistej „rywalizacji o znaczenia” zostały przyjęte „właściwe” opisy podpowiadane przez nadawcę komunikatów, czyli w tym przypadku prasę IV RP. Służy to nie tylko delegitymizowaniu poprzedniego ładu, odrzuceniu III RP jako państwa odartego i odzierającego $z$ godności, ale także legitymizuje nowo wybraną władzę. Argumentacyjna konsekwencja może przyczynić się do tego, aby legitymizacja władzy była nie tyle normą regulatywną (narzuconą z zewnątrz), ile rodzajem zinternalizowanego przekonania o zasadności podlegania danej władzy, typem wiary legitymizacyjnej, której źródła mogą mieć racjonalny, ale też wyłącznie emocjonalny charakter (Rychard, Sułek 1988).

W zasadzie od początku w centrum swej strategii argumentacyjnej prasa IV RP ustawiła relację elity-masy czy elity-,,zwykli Polacy” . Krytykowała ład i system III RP: „[...] który jest oligarchią, czyli władzą nielicznych w swoim 
interesie. To państwo słabe, które jest brzemieniem dla zwykłych obywateli, a żyznym żerowiskiem dla potentatów" (Wildstein 2017). Taka Polska w okresie transformacji była krajem niespełniającym nadziei, „państwem cwaniaków” (Pawlicki 2014), w którym elity prezentowały postawę wyższości wobec pozostałych grup społecznych. Kwestionowano jednak nie tylko moralność elit. W tekstach odnajdujemy również retorykę utraty - twierdzono, że podstawowe idee i wartości mające kształtować porządek normatywny w państwie utraciły substancjalne znaczenie. Na rozwiązanie redakcji tygodnika „Uważam Rze" Bronisław Wildstein (2012) zareagował:

„Do znudzenia powtarzam, że III RP to świat na opak. Szuje nauczają moralności, oszuści rozliczają prawdomównych, zdrajcy wystawiają cenzurki patriotyzmu. A wszystko to dzieje się pod najwyższymi hasłami wolności, godności i praw człowieka".

Wśród kategorii odnoszących się do elit pojawiają się takie słowa, jak: „szuje”, „oszuści”, a nawet „zdrajcy”. To jednoznaczny przykład retoryki dyskredytacji polegającej na odmowie oponentom politycznym moralności. Przeciwstawieni im zostają „prawdomówni”, którymi w domyśle mają być dziennikarze tworzący środowisko mediów IV RP, ludzie tzw. dobrej zmiany, członkowie patriotycznego obozu. Ten rodzaj wypowiedzi można nazwać retoryką wstydu za będących przy władzy i za ład normatywny. Piszący prezentują się tu jako ci sprawiedliwi, zawstydzeni tym, jaki był dotychczas porządek społeczny w Polsce i jak wyglądało sprawowanie władzy przez koalicję PO-PSL. Poprzednio rządzący nie zasługiwali i nie zasługują na szacunek, na to, aby legitymizować ich rządy:

„[...] przecież elity III RP w oczywisty sposób kłamią nie tylko w tej jednej sprawie i nie tylko w ten sposób się w oczach ludzi młodych kompromitują. Gdy spontanicznemu wśród młodych kultowi bohaterów z powązkowskiej «Łączki» przeciwstawiają odgórny kult mjr. Baumana, gdy próbują prawdziwe święta narodowe zastąpić obchodami rocznicy mętnego dealu w Magdalence i odrzucają barwy narodowe na rzecz różu lub tęczy, potwierdzają w oczach młodego Polaka, że są mu obce i wrogie" (Ziemkiewicz 2013).

Taki rodzaj komentarza to forma wyrażenia rozczarowania zarówno elitami III RP, jak i sposobem ich działania, tym, co mają do zaoferowania na przykład młodym ludziom.

W analizie strategii argumentacyjnych warto też zwrócić uwagę na to, w jaki sposób w prawicowej prasie są opisywani „zaadaptowani”. Grupa ta w zasadzie została połączona $z$ elitami III RP lub co najmniej ulokowana blisko nich — jako ci, którzy na zmianach w Polsce skorzystali bądź po prostu uwierzyli w „dobre opowieści" o polskiej transformacji i przez swoje działania reprodukują dysfunkcjonalny, niesprawiedliwy ład III RP. Ludzie ci w prasie IV RP niekiedy są określani jako „lemingi” - osoby skoncentrowane na własnym losie, zajęte pracą w korporacjach i niedostrzegające „prawdy” o stopniu upadku państwa 
i postępującej niesprawiedliwości. Nie znają prawdy, gdyż zostali wyhodowani na propagandowym przekazie mediów podporządkowanych ówczesnej władzy. Należy im pomóc, wytłumaczyć, jak jest naprawdę (Zybertowicz 2013). Taka lokalizacja „zaadaptowanych” pomaga prasie IV RP w skonstruowaniu granicy oddzielającej wygranych i przegranych.

Krytyka ładu po Okragłym Stole była (i jest) prowadzona w duchu demokratycznego proceduralizmu, czyli na podstawie założenia, iż legitymizacja władzy i podejmowane decyzje polityczne wynikają z ustalonych wcześniej ram i reguł postępowania, których należy przestrzegać. Istotne stają się zatem taka forma i wybrana procedura wyłaniania władzy, w której odrzuca się wszelkiego rodzaju stronniczość. Warunku tego, zdaniem krytyków, nie spełniały porozumienia „okrągłostołowe”, wzajemne uzgodnienia między stroną opozycyjną i rządową, ponieważ kształtujący się ład polityczny, kulturowy, gospodarczy nie uwzględniał preferencji obywateli („zwykłych Polaków”), lecz był jedynie realizacją interesów elit poprzedniego reżimu i tych nowych, wyłaniających się, które rekrutowały się spośród części uczestników Okrągłego Stołu. Porozumienia te przedstawiane są w mediach IV RP jako: „mętny deal” (Ziemkiewicz 2013), „magdalenkowy układ” (Ziemkiewicz 2014), porozumienie „starych elit z nowymi elitami” (Fedyszak-Radziejowska 2014) ponad głowami „zwykłych Polaków". Zdrada elit ma również polegać, według prasy IV RP, na porzuceniu ideałów Solidarności oraz na tym, że z „bohaterów podziemia” zmienili się oni w opływających w zbytki „notabli”, którzy za pomocą dóbr materialnych eksponują swój społeczny status. Pisze o tym między innymi Zdzisław Krasnodębski (2013):

„Ktoś może powiedzieć, że zmiana poglądów to przecież nie zdrada, zmiany przyjaciół i sojuszników także się zdarzają, że w polityce nie liczą się lojalność ani przyzwoitość. Nowe czasy wymagają przystosowania się, nowych umiejętności, pragmatyzmu i elastyczności [...] Ktoś może powiedzieć, że w gruncie rzeczy ów proces przedzierzgnięcia się dawnych, mniej lub bardziej bohaterskich, bohaterów podziemia $\mathrm{w}$ jednym swetrze $\mathrm{w}$ dzisiejszych zadowolonych $\mathrm{z}$ siebie notabli rozpierających się w limuzynach to rzecz najnormalniejsza w świecie".

Elity III RP zdobyły władzę dla niej samej, dla bogacenia się, a nie dla polepszenia losu „zwykłych ludzi”.

Strategie argumentacyjne stosowane $\mathrm{w}$ prasie IV RP mają na celu odczarowanie elit III RP, ukazanie ich w możliwie najbardziej negatywnym świetle, przeciwstawienie ich „zwykłym Polakom”. Piotr Zaremba (2014) tak komentuje stenogramy taśm z restauracji „Sowa i Przyjaciele”:

„[... z zwykli ludzie mogą nie rozumieć subtelności sporów o niezależność banku centralnego. Ale zauważą, że podsłuchani dygnitarze zmawiają się wulgarnym językiem i także to, ile płacą za swoje potrawy [...]. Robi to wszystko wrażenie lekceważenia Polaków, a w zestawieniu z sutym rachunkiem to wrażenie zmienia się w pewność. To krok w kierunku odczarowania "pięknych i mądrych", którzy nami podobno rządzą". 
W strategiach argumentacyjnych w stosunku do „elit III RP” używana jest również pejoratywna kategoria „układu”, który jest obecny w różnych sferach działania państwa, jego instytucji:

„Wprawdzie przyjęto procedury i normy demokracji, a także wolnego rynku, ale zostały one zaszczepione wewnątrz dawnych porządków i układów personalnych, co prowadziło do ich fundamentalnego wypaczenia. Pozostawieni na swoich uprzywilejowanych stanowiskach i sterujący najważniejszymi korporacjami — przede wszystkim prawniczymi - członkowie nomenklatury uwłaszczyli się na państwowym majątku i stworzyli oligarchiczny układ, który wkrótce pozwolił im, już z demokratycznymi procedurami, odzyskać władzę" (Wildstein 2014).

Ten fragment artykuł Bronisława Wildsteina to przykład retoryki demaskatorskiej - „tłumaczy się” odbiorcom, o co chodziło w transformacji, a także podaje się w wątpliwość logikę wyborów w Polsce. Ten sam typ retoryki występuje $\mathrm{w}$ komentarzach odnoszących się do podmiotowości i wolności obywateli:

„Czy jeszcze jesteśmy wolnym społeczeństwem wolnych ludzi? Mamy przecież do czynienia z jednoczesnym wystąpieniem trzech zjawisk: zdominowaniem mediów przez jedną grupę wpływu, ukierunkowaniem służb specjalnych na kontrolowanie własnego społeczeństwa oraz z praktycznym funkcjonowaniem zjawiska tzw. nomenklatury, czyli zablokowania dostępu zwykłych obywateli do coraz większej liczby stanowisk i miejsc pracy w kraju. Te stanowiska i pieniądze zarezerwowane są tylko dla ludzi powiązanych z partią lub układem rządzącym" (Karnowski 2013).

Rządy Platformy Obywatelskiej i Polskiego Stronnictwa Ludowego zatem nie tylko utrzymywały dysfunkcjonalny porządek społeczny, ale również ograniczały wolność obywateli, ustawiając się tym samym w kontrze do „zwykłych ludzi".

W roli odpowiedzialnych za dysfunkcje III RP zostały obsadzone również instytucje europejskie, a precyzyjniej - unijne. Brukselskie elity wskazywane są w dyskursie IV RP nie tylko jako współwinowajcy złej sytuacji w Polsce, ale także jako grupa, która w konsekwentny sposób prowadzi politykę zastąpienia wartości tradycyjnych, polskich, liberalnymi, kosmopolitycznymi, które są charakterystyczne dla demokracji zachodnich. Elity III RP ma również cechować swoisty serwilizm wobec władz europejskich, zwłaszcza wobec Niemiec. W jednym $z$ artykułów „wSieci” napisano:

„«Prymus» [Donald Tusk - M.K.] podpisuje wszystko, co mu podsuwa Berlin sam lub via Bruksela [...]. W sumie to nie wiadomo, czy Tusk faktycznie postanowił uznać niemieckość za własną stronę swojej świadomości [...]. Może jednak Tusk faktycznie postanowił wpisać się na współczesną «volkslistę». W przyjaznej i bezpiecznej dla polityków PO atmosferze u Moniki Olejnik wyjawił, że w domu śpiewa kolędy po niemiecku" (Sieradzki 2014).

W tym przypadku mamy do czynienia $z$ dyskredytacją identyfikacyjną, gdyż o premierze pisze się $\mathrm{w}$ zasadzie jako o nie-Polaku, spełniającym oczekiwania innych państw, przede wszystkim Niemiec. 
Komentarze, w których akcentuje się sprawczą rolę brukselskich elit, są istotne w jednej z kluczowych „spraw”, co można traktować jako egzemplifikację strategii argumentacyjnych środowiska „dobrej zmiany”. Chodzi o tzw. problem kryzysu migracyjnego. W prasie IV RP winą za zwiększanie się liczby uchodźców, migrantów zmierzających $\mathrm{w}$ stronę europejskich granic obarcza się unijne elity, z konkretnym wskazaniem na wybranych liderów państw europejskich, zwłaszcza Angelę Merkel. To „oni” odpowiadają za „fale migrantów”, „najeźdźców”, „za napływ młodych i zdrowych mężczyzn”, którzy zamiast bronić swojej ojczyzny, chcą forsować „nasze granice” i zagrażają naszemu bezpieczeństwu (zwłaszcza „naszych kobiet”) (Nykiel 2015; Rybińska 2016; Wildstein 2016; Ziemkiewicz 2015b, 2015a). W przypadku kwestii migracji budowanie granic wspólnoty interpretacyjnej dokonuje się przez wzbudzanie lęków, straszenie Polaków „innymi” i „obcymi”. Imigranci portretowani są jako potencjalni terroryści, forpoczta fundamentalistów dążących do islamizacji Europy i Polski. Naszych granic należy bronić, a skutecznie może tego dokonać rząd odwołujący się do narodowej wspólnoty, tradycji i wartości, na których się ona opiera, rząd, który będzie opierał się naciskom i samobójczej polityce Brukseli i Berlina. Stoi za nim obóz „dobrej zmiany”, a za granicą - wszyscy ci, którzy krytycznie patrzą na osiedlanie się uchodźców w ich krajach (np. Viktor Orban). Zwraca przy tym uwagę dochodzące do głosu w prasie IV RP przekonanie, że odpowiednimi regulacjami, ustawami można powstrzymać zmiany społeczne i zmiany kulturowe.

Sprawę migrantów przedstawia się jako kolejną próbę narzucenia nam swojej woli przez państwa zachodnie, które kierują się lewicowymi wartościami oraz polityczną poprawnością (wobec pierwszego i drugiego stosuje się ironię i retorykę szydzenia). „Nasz”, polski opór w tym przypadku to część narracji o odzyskanym państwie i przywróconej „zwykłym ludziom” godności. „Dobra opowieść" w tym przypadku koncentruje się na narodzie, który broni swej tożsamości i przeciwstawia się niedemokratycznym elitom. Fala takich zmian pojawia się nie tylko w Polsce, ale też w innych państwach. Jest to między innymi rezultat przełamania monopolu informacyjnego, który miał charakteryzować dotychczasowy sposób funkcjonowania mediów w Polsce i części europejskich państw:

„To, co możemy obserwować ostatnio, czego przejawem był sukces Fideszu i PiS, zwycięstwo Trumpa czy Brexit, to bunt narodów w obronie swojej tożsamości. Bunt przeciw dyktatowi elit, które demokrację stopniowo zastępowały oligarchią [...]. Obecne lamenty establishmentu nad postprawdą to w ogromnej mierze żale nad utraconym monopolem" (Wildstein 2017a).

W tym komentarzu można dostrzec zarówno retorykę przemiany - narodów zniewolonych w wolne i świadome swej tożsamości, jak i retorykę „sprawiedliwości dziejowej”, gdy wpływy traci dotychczasowy establishment.

Narracja w prasie IV RP jest ustrukturyzowana. Można w niej wyróżnić przewodni komunikat, wskazać oś podziału wyznaczającą granice wewnątrz 
społeczeństwa oraz wymienić istotne „sprawy” wkomponowane w „dobrą opowieść".

Strategie argumentacyjne $\mathrm{w}$ prasie IV RP są zbliżone do stosowanych przez populistów. Polegają na przeciwstawieniu „ludu” bądź „narodu” „elitom” (Müller 2017, s. 8-9). „Naród” mają tworzyć „zwykli ludzie”, którym należy się odzyskanie godności. Populistyczna antyestablishmentowa retoryka odwołuje się zatem do gniewu zwykłych ludzi (Müller 2017, s. 13-17). Należy jednak pamiętać, że $\mathrm{w}$ analizowanej sytuacji populiści nie pochodzą spoza systemu partyjnego. Są jego częścią, przez co można ich uznać za reprezentantów elit symbolicznych. Publiczności, odbiorcom prezentują się jednak jako ludzie spoza elity, spoza „układu”, którzy tak jak „zwykli Polacy” byli odsunięci przez decydentów na boczny tor. Media IV RP w stosunku do siebie wciąż posługują się kategoriami: „niepokorni” i „niezależni”, tak jakby uprawiali swoiste partyzanckie dziennikarstwo. Nawet jeśli ich medialne firmy rosną $w$ siłę (tak jak w przypadku spółki Fratria) i są stale obecni $\mathrm{w}$ mediach (również prowadząc własne programy telewizyjne), to wciąż obsadzają się w roli pisarzy drugiego obiegu, osaczonych i prześladowanych. Ich rywalami są media wobec nich antagonistyczne, zwłaszcza „Gazeta Wyborcza” (i inne media związane z Agora, np. Radio TOK FM), „Newsweek”, „Polityka”, „TVN” - członkowie i reprezentanci establishmentu III RP. W stosunku do pracujących tam dziennikarzy stosowna jest retoryka dyskryminacyjna. Określa się ich jako: propagatorów „pedagogiki wstydu”, część „przemysłu pogardy” czy „resortowe dzieci”, które korzystają z przywilejów w III RP, ponieważ ich rodzice, dziadkowie mieli wysokie pozycje w PRL i w PZPR.

Krytyka i próba delegitymizacji elit jest warunkiem niezbędnym (ale nie wystarczającym), aby można było mówić o posługiwaniu się populistyczną retoryką. Drugi warunek to sprzeciw wobec pluralizmu, co przejawia się zwłaszcza w tym, że populiści wyłącznie sobie przypisują prawo do reprezentowania narodu, a co więcej - niekiedy siebie utożsamiają z narodem, na przykład pytając o to, „ilu nas jest” lub piętnując „post-Polaków”. Takich granic wewnętrznych dotyczą choćby teksty Macieja Pawlickiego. Jeden z nich został napisany w 2012 roku i jest przykładem retoryki opartej na kategoryzacji My-Oni. Ma charakter retoryki mobilizacyjnej, chodzi o sprawdzenie własnych szeregów, policzenie się. Autor pyta:

„Ilu nas jest — bezczelne pytanie, prawda? Niby wiadomo, wciąż $38 \mathrm{mln}$, z czego jakieś 2 mln w Irlandii i Anglii, kilkaset tysięcy u Niemca i gdzieś tam jeszcze po kątach Europy i świata [...]. Ale pytam serio: ilu w sierpniu roku 2012 nas jest, Polaków, którzy chcą być Polakami, których obchodzi los polskiej wspólnoty, ich własne państwo, którzy chcą żyć wedle ideałów polskiej tradycji, kultury i historii, a więc oddzielając szlachetność od podłości, solidarność od zdrady, wolność od zniewolenia? [...] Ilu jest Polaków, a ile postpolskich mutantów czy też prepolskich larw, tak twórczo dziś hodowanych przez medialny panświnizm? I czy 
Zabiegi retoryczne w mediach IV RP

\begin{tabular}{|c|c|}
\hline \multicolumn{2}{|c|}{ Struktura narracji o stopniowej degradacji państwa zawłaszczonego przez elity } \\
\hline Transmitowany komunikat & $\begin{array}{l}\text { Ład po Okrągłym Stole należy zmienić. } \\
\text { Potrzebny jest nowy porządek konstruowany przez środowiska kon- } \\
\text { serwatywne. } \\
\text { Stare elity III RP są winne upadkowi państwa i niesprawiedliwości } \\
\text { społecznej. } \\
\text { W Polsce potrzebny jest konserwatywny zwrot. } \\
\text { Nadchodzi czas „dobrej zmiany” dla „zwykłych Polaków”. }\end{array}$ \\
\hline $\begin{array}{l}\text { Główna oś podziału spo- } \\
\text { łecznego }\end{array}$ & Elity III RP-zwykli Polacy, wygrani-przegrani \\
\hline \multicolumn{2}{|l|}{ Typy argumentacji } \\
\hline ekonomiczna & $\begin{array}{l}\text { Uwłaszczone na państwowym majątku - „stare i nowe” elity za- } \\
\text { właszczyły państwo. } \\
\text { Nierówności i niesprawiedliwa dystrybucja dotknęły zwykłych lu- } \\
\text { dzi. }\end{array}$ \\
\hline polityczna & $\begin{array}{l}\text { Liberałowie i lewica skompromitowali się. } \\
\text { W Polsce dokonuje się konserwatywny bunt. } \\
\text { Najważniejszy typ wspólnoty to naród. }\end{array}$ \\
\hline religijna & $\begin{array}{l}\text { Odejście od chrześcijańskiej, katolickiej tradycji okazało się niewła- } \\
\text { ściwe. } \\
\text { Potrzebny jest powrót do katolicyzmu (archetyp Polak-katolik). }\end{array}$ \\
\hline moralna & $\begin{array}{l}\text { Opowiedzenie się po stronie opozycji wobec elit III RP to wybór } \\
\text { o charakterze moralnym. }\end{array}$ \\
\hline \multicolumn{2}{|r|}{ Wybrane „sprawy” i zastosowana argumentacja } \\
\hline Katastrofa smoleńska & $\begin{array}{l}\text { Upadek i słabość państwa. Odpowiedzialność elit III RP. Konse- } \\
\text { kwencja działania „przemysłu pogardy”. }\end{array}$ \\
\hline Teczka Wałęsy & $\begin{array}{l}\text { Przenikanie się starych i nowych elit. Polska wciąż jest krajem post- } \\
\text { komunistycznym z istotną rolą tajnych służb. Konieczna była deko- } \\
\text { munizacja w początkach III RP. Autorytety III RP są fałszywe. }\end{array}$ \\
\hline $\begin{array}{l}\text { Edukacja seksualna i prawo } \\
\text { dotyczące prokreacji }\end{array}$ & $\begin{array}{l}\text { Zagrożenie nihilizmem i wpadnięciem w pułapkę politycznej po- } \\
\text { prawności. Gender to zagrożenie dla naszej tożsamości i tradycji. } \\
\text { Odejście od wiary i wartości definiujących naszą wspólnotę. }\end{array}$ \\
\hline Kryzys migracyjny & $\begin{array}{l}\text { Zagrożenie islamizacją Europy i Polski. Zagrożenie terroryzmem. } \\
\text { Narzucanie przez brukselskie elity niekorzystnych dla nas rozwią- } \\
\text { zań. „To najeźdźcy, nie uchodźcy” (Ziemkiewicz 2015b). }\end{array}$ \\
\hline Kult „żołnierzy wyklętych” & $\begin{array}{l}\text { Wykluczeni z dyskursu o bohaterach. Gotowe wzorce osobowe dla } \\
\text { młodzieży, którą charakteryzuje konserwatywny bunt. }\end{array}$ \\
\hline
\end{tabular}

Opracowanie własne. 
można spośród owych mutantów i owych larw awansować do grona Polaków?" (Pawlicki 2012).

Retoryka dyskryminacyjna służy tu do wykluczenia z narodowej wspólnoty tych określonych jako „postpolskie mutanty” i „prepolskie larwy”, które są „hodowane przez medialny panświnizm”. Jest to przykład praktyk dehumanizacyjnych polegających na stosowaniu wobec innych (już nie-Polaków lub jeszcze nie Polaków) miana istot „hodowanych” jak zwierzęta. Są to, ci wszyscy, którzy nie spełniają kryteriów zdefiniowanych przez autora i akceptują „dobrą opowieść" konkurencyjnych mediów. W innej wypowiedzi ten sam autor wprowadza określnie „post-Polacy”:

„Czy chcemy istnieć? Czy chcemy być Polakami? [...] A ilu wytresowanych przez antypolską propagandę tubylców już Polski i polskości po prostu nienawidzi? [...] Żyją jednak w kraju nad Wisłą tysiące (miliony?) Polaków i - z przykrością, ale chyba trzeba ich tak nazwać - post-Polaków, którzy nadal (znowu?) państwo niemieckie uznają za cudną metropolię, do której przedpokojów możemy aspirować, $z$ entuzjazmem przyjmując wszystkie cywilizacyjne rozkazy pruskiego Berlina i coraz bardziej pruskiej Brukseli. [...] Bez wątpienia ujawnienie dzisiaj pełnej listy płac urzędników III RP i medialnych koryfeuszy pobierających pensje u obcych dworów $\mathrm{w}$ ten czy inny sposób uzdrowiłoby życie polityczne w Polsce. [...] «Gazeta Wyborcza», media postkomunistyczne oraz polskojęzyczne media niemieckie wykonują od 25 lat gigantyczną pracę, by rozbudować polskie poczucie niższości, kompleksy, że jesteśmy gorsi, głupi, niegodni. [...] Wrzaski niemieckich kapo i rodzimych jurgieltników, szczególnie bezwstydnych, są groteskowe, ale batalia jest bardzo silna. O narodową duszę" (Pawlicki 2016).

Zwycięstwo Prawa i Sprawiedliwości zostało w tym tekście przedstawione jako początek „wybijania się na niepodległość”. Są jednak tacy, twierdzi autor, którzy proces ten chcą zakłócić. Jest to przykład retoryki demaskatorskiej, gdyż oponentom politycznym zarzuca się zdradę, pracę dla innych, „pobieranie pensji u obcych dworów". Te przeszkody na drodze do niepodległości stawiają owi "post-Polacy”, „media postkomunistyczne oraz polskojęzyczne media niemieckie”. Pojawia się też retoryka dyskryminacyjna, gdy przeciwnicy zostają określeni jako „kapo”. Uruchomiona jest również zasada dyskredytacji autora (zob. Nowicka 2014) — oponenci medialni i polityczni nie mają w zasadzie prawa się wypowiadać i komentować tego, co się dzieje w kraju, bo reprezentują obce interesy i są niewiarygodni. Tego rodzaju retoryka ma wytworzyć dystans między liberalnymi mediami a „zwykłymi Polakami”. Podkreślanie zależności elit III RP od rządów innych państw, a zwłaszcza sugerowanie służebnej roli rządu PO-PSL wobec Niemiec, jest konsekwentnie wykorzystywane w strategiach argumentacyjnych prasy IV RP. Przykładem może być komentarz Witolda Gadowskiego (2013):

„Polski establishment nie udowodnił, że jest na tyle niepodległy, aby wyjaśnić okoliczności śmierci polskiego prezydenta i elity polskiego społeczeństwa [...] 
obywatel coraz mocniej zdaje sobie też sprawę z faktu, że rządzący bezceremonialnie, $z$ użyciem medialnej i administracyjnej siły, starają się dokonać gwałtu zbiorowego na jego zdrowym rozsądku. Rząd Tuska i zależne od niego media zachowują się jak podwórkowy chuligan - własnemu społeczeństwu gotowi spuścić łomot, ale przed silniejszym, przed rządem Putina przyjmują pokorne postawy i udają, że... pada deszcz".

Elity medialne dyskredytuje również przynależność do „układu”, to że w redakcjach wciąż pracują „resortowe dzieci” uległe i konformistyczne, a nie krytyczne i dociekliwe. Andrzej Zybertowicz (2014) komentował to w ten sposób:

„Ale dyskurs publiczny może być ograniczony, ba, paraliżowany, także przez we-
wnętrzny układ sił. Na przykład gdy właścicielem stacji telewizyjnej jest były
współpracownik tajnych służb PRL [...]. Jeśli w jakiejś redakcji wpływowe grono
stanowią resortowe dzieci, nie należy się dziwić, że młodzi dziennikarze dopaso-
wują się do ich sposobów myślenia, a także sposobów nie-myślenia, tj. unikania
podejmowania drażliwych tematów. Wcale nie jest potrzebne tu spiskowe do-
pinanie spraw i wysyłanie jasnych poleceń - wystarczy ludzki instynkt stadny,
zwykły konformizm i uległość podyktowana obawą przed utratą pracy. Rzecz nie
dotyczy tylko rozliczenia z przeszłością. Chodzi o dynamikę zjawisk obecnych”.

W tym przypadku chodzi o ustawę lustracyjną i rolę, jaką w kształtowaniu III RP odgrywały (tajne) służby, choć teza o „unikaniu podejmowania drażliwych tematów" dotyczy nie tylko tego.

Zdefiniowanie tego, czym jest naród i kto do niego należy, jest ważnym elementem narracji „o odzyskiwaniu państwa”, o czym świadczą strategie argumentacyjne stosowane $\mathrm{w}$ tekstach prasy IV RP. Naród definiowany jest tam w myśl założeń esencjalizmu — naszą grupę, wspólnotę (narodową) postrzega się jako realnie istniejącą. Oznacza to, że naród ma swoje wyraźne i określone granice. Obcy zaś to nie tylko obcokrajowcy, żyjący poza terytorium państwa, ale również ci, którzy mieszkają w Polsce, ale należą do wrogiej grupy, nie spełniają oczekiwań i kryteriów stawianych członkom „naszej” wspólnoty. Takie nakreślenie granic może wzmacniać tendencję do dehumanizowania „innych”, „onych”, tych którzy nie są „z nami” (Drogosz, Bilewicz, Kofta 2012, s. 8-9). Odniesienia do kwestii integralności narodu są zatem istotne $\mathrm{w}$ strategiach argumentacyjnych. Narodowa przynależność nakłada na jednostkę określone prawa i obowiązki, ale przede wszystkim wiąże się z poczuciem dumy narodowej. Naród ma być najszerszą grupą, z jaką człowiek potrafi się zidentyfikować we współczesnym świecie. Decyduje o tym przynależność do wspólnoty kulturowo-historycznej. W artykule Polskość jako los Bronisław Wildstein (2013) napisał:

„[...] przynależność do narodu wpisuje moje losy w dzieje konkretnej zbiorowości. Zrozumienie tego wiąże się także $z$ odkryciem emocjonalnego związku, jaki czuję w odniesieniu do osób połączonych ze mną wspólnotą losu. Zaznaczyć trzeba, że jest to wspólnota kulturowo-historyczna, nie etniczna, z którą ta pierwsza może, ale nie musi się pokrywać". 
Polskość, czyli przynależność do narodu, „tłumaczona” jest jako uczestnictwo we wspólnocie doświadczeń, podzielanym losie i historii. Jest to istotne, media IV RP przedstawiają bowiem konkurencyjną elitę symboliczną (elitę III RP) jako odwołującą się do zupełnie innych „przeżyć pokoleniowych” uformowanych $\mathrm{w}$ dysfunkcjonalnym ładzie potransformacyjnym. Dlatego tamten establishment chce przede wszystkim bronić dotychczas istniejącego porządku, co w istocie oznacza obronę własnych pozycji i zasobów (materialnych i niematerialnych). Grupę tę charakteryzować ma ponadto bezrefleksyjny zwrot w stronę kosmopolityzmu i politycznej poprawności, odejście od tradycji narodowej, permisywizm, relatywizm, pochwała indywidualizmu i zadowolenie $z$ imitacyjnej formy modernizacji. Konflikt, zwłaszcza ten odwołujący się do różnic kulturowych, pozwala na konstruowanie ekskluzywnej formuły narodu, na kategoryczne decydowanie o tym, o kim możemy mówić jako członku wspólnoty narodowej (tak aby był to „nasz” naród).

W początkach transformacji w narracji odnoszącej się do powrotu Polski do Europy istotną rolę odgrywało wskazywanie pożądanych wzorców zachowań. Określano wtedy niezbędne kierunki działania i to, jak ludzie powinni się zmienić, jeśli chcą stać się i poczuć się Europejczykami. Od obywateli wymagano „pracy nad sobą” dostosowania się do nowych warunków, mówiąc inaczej oczekiwano od nich adaptacji. W retoryce strategii argumentacyjnych mediów IV RP i obozu politycznego „dobrej zmiany” zmienić się mieli przede wszystkim rządzący (ale to naturalne, bo temu służą kampanie wyborcze i wybory) i zmienić się ma państwo, niekoniecznie zaś potrzeba zmiany dotyczy obywateli. Ci, od których wcześniej oczekiwano potwierdzania swej przydatności, otrzymali komunikat, że to państwo i rządzący mają się do nich dostosować, a nie oni do państwa.

Strategie argumentacyjne prasy IV RP pozwoliły również na wprowadzenie do centrum dyskursu publicznego takiego języka opisu rzeczywistości, który wcześniej był piętnowany przez mainstreamowe elity symboliczne - jako zbyt radyklany, nienawistny - bądź pozostawał na marginesie. Coraz częściej jako prawomocne w dyskursie publicznym występują sformułowania nacjonalistyczne, ksenofobiczne, spełniające $\mathrm{w}$ zasadzie wszelkie kryteria mowy nienawiści. Nastąpiło uprawomocnienie skrajnych form wypowiedzi padających ze strony obozu „dobrej zmiany”, który jednocześnie nie jest w stanie ich kontrolować. Może to okazać się szczególnie niebezpieczne ze względu na ogromne zwiększenie skali mowy nienawiści w internecie.

Istnienie dychotomii My-Oni nie jest niczym nowym w systemach demokratycznych. W zasadzie stanowi ich immanentną, nieusuwalną cechę i tym łatwiej bywa rozgrywane przez pewne środowiska polityczne $\mathrm{w}$ formie swoistej blame game, której rezultatem ma być uzyskanie od większości obywateli uznania mocy kontrolowania procesów decyzyjnych w polityce i legitymacji projektowanego przez siebie ładu społecznego. Istotne jest to, jak owa dychotomia jest rozgrywana w celu rekonstrukcji demokratycznego ładu. Etykieta „Oni” 
Zestawienie 2

Wybrane kategoryzacje i retoryki stosowane w strategiach argumentacyjnych prasy IV RP

\begin{tabular}{|c|c|c|}
\hline \multirow[b]{2}{*}{$\begin{array}{l}\text { Kategoryzacje odno- } \\
\text { szące się do nomina- } \\
\text { lizacji „oni” }\end{array}$} & Etykiety i argumenty & Cel \\
\hline & $\begin{array}{l}\text { Elity, zblatowane elity, nieuczciwe elity, establi- } \\
\text { shment III RP, wygrani, stare cwaniaki, zdradza- } \\
\text { jący ideały Solidarności, część przemysłu pogar- } \\
\text { dy, lewica, lewactwo, resortowe dzieci, medial- } \\
\text { ny establishment, młodzi wykształceni z wiel- } \\
\text { kich ośrodków, lemingi. }\end{array}$ & $\begin{array}{l}\text { Uogólniający charakter } \\
\text { kategoryzacji skutkuje } \\
\text { przypisaniem trwałej ne- } \\
\text { gatywnej etykiety. }\end{array}$ \\
\hline $\begin{array}{l}\text { Wybrane typy retory- } \\
\text { ki: } \\
\text { dyskryminacja } \\
\text { identyfikacyjna }\end{array}$ & $\begin{array}{l}\text { Elity się skompromitowały, więc ich czas się } \\
\text { skończył. Establishment III RP działa we wła- } \\
\text { snym interesie lub w interesie innych państw } \\
\text { (np. Niemiec). }\end{array}$ & \multirow{5}{*}{$\begin{array}{l}\text { Delegitymizacja dotych- } \\
\text { czasowych elit. Wyłącze- } \\
\text { nie bądź ograniczenie ro- } \\
\text { li tej grupy w grze o kon- } \\
\text { strukcję znaczeń. Przy- } \\
\text { pisanie „elitom III RP” } \\
\text { braku szacunku i pogar- } \\
\text { dy do „zwykłych Pola- } \\
\text { ków". }\end{array}$} \\
\hline $\begin{array}{l}\text { dyskryminacja ide- } \\
\text { ologiczna }\end{array}$ & $\begin{array}{l}\text { Bezideowcy, skoncentrowani na własnym inte- } \\
\text { resie, kosmopolityczna „tęczowa” lewica, libe- } \\
\text { rałowie. }\end{array}$ & \\
\hline $\begin{array}{l}\text { dyskryminacja bio- } \\
\text { graficzna }\end{array}$ & $\begin{array}{l}\text { Członkowie „okrągłostołowego” układu, opo- } \\
\text { wiadający się za porozumieniem z komunista- } \\
\text { mi, niekiedy wprost wywodzący się z reżimo- } \\
\text { wych, komunistycznych elit. }\end{array}$ & \\
\hline $\begin{array}{l}\text { dyskryminacja kla- } \\
\text { sowa }\end{array}$ & $\begin{array}{l}\text { Niesprawiedliwość społeczna to wina elity. Ci, } \\
\text { którzy przynależą do elit, stracili moralne pra- } \\
\text { wo dyktowania innym, jak należy żyć. Grupy } \\
\text { zamknięte w uprzywilejowanych kastach nale- } \\
\text { ży izolować od wpływu na państwo. }\end{array}$ & \\
\hline retoryka walki & $\begin{array}{l}\text { Konieczna jest walka ze starym system, ukła- } \\
\text { dem, złogami (komunistycznymi). }\end{array}$ & \\
\hline $\begin{array}{l}\text { retoryka odzyskanej } \\
\text { godności }\end{array}$ & $\begin{array}{l}\text { Należy zwrócić się ku mądrości zwykłego czło- } \\
\text { wieka. Trzeba słuchać „,suwerena”, który wybrał } \\
\text { „dobrą zmianę” (wykorzystywany przez populi- } \\
\text { stów archetyp „mądrości ludu”). Przywracanie } \\
\text { Polakom godności i nadziei. }\end{array}$ & $\begin{array}{l}\text { Nobilitacja } \quad \text { „zwykłych } \\
\text { Polaków”. } \\
\text { poparcia dla rekonstrukie } \\
\text { cji ładu } \\
\text { tycznołeczno-poli- }\end{array}$ \\
\hline retoryka zagrożenia & $\begin{array}{l}\text { Zagrażają nam „inni”, „obcy”, odwołujący się } \\
\text { do nihilistycznych ideologii. Strach budzą mi- } \\
\text { granci i uchodźcy (islamizacja, terroryzm), le- } \\
\text { wactwo (permisywizm, socjalizm, multikulti), } \\
\text { gender (zagrożenie tradycji, rodziny, niebezpie- } \\
\text { czeństwo dla dzieci). }\end{array}$ & $\begin{array}{l}\text { Delegitymizacja bruksel- } \\
\text { skich elit. Wskazanie na } \\
\text { kompromitację polityki } \\
\text { pluralizmu kulturowego } \\
\text { i wielokulturowości. }\end{array}$ \\
\hline
\end{tabular}

Opracowanie własne.

bowiem nie tylko może zostać przypisana wybranym członkom elit, aktorom politycznym czy celebrytom, ale również może być przeniesiona na instytucje reprezentujące dotychczasowy porządek. Wtedy próba zmiany porządku insty- 
tucjonalnego staje się częścią strategii argumentacyjnej, która polega na narracji o konieczności naprawy źle działającego państwa i niesprawiedliwych sądów, a przede wszystkim rozbijania kast usadowionych na wysokich pozycjach systemu politycznego. Drugorzędne zaś staje się to, w jakim stopniu realne i oparte na obiektywnych danych są: diagnoza mówiąca o upadku państwa i oskarżenia kierowane w stronę źle działających instytucji. Istotnym celem jest „odzyskanie" tych instytucji, co w sposób bezpośredni może kolidować z procesem demokratyzacji systemu.

W sferze publicznej trwa nieustanna konfiguracja przestrzeni politycznej. W Polsce problematyczność przebiegu i rezultatów polskiej transformacji umożliwiła prawicowemu środowisku politycznemu wykorzystanie narracji o straconej szansie polskiego społeczeństwa. Dominująca wcześniej narracja o stopniowej modernizacji, wzrastającym dobrobycie, o „przenoszeniu Polski ze Wschodu na Zachód" straciła moc i została skonfrontowana z narracją o stopniowym upadku państwa, zawłaszczeniu jego majątku przez elity oraz podziale na przegranych i wygranych. Do dyskursu zdołano wprowadzić hasła o konieczności odzyskania państwa i jego instytucji dla „zwykłych Polaków". Złożone i wielowymiarowe zjawiska polityczne i gospodarcze zostały sprowadzone do jednego wymiaru - szkodliwych decyzji politycznych i jednego odpowiedzialnego za nie czynnika, czyli rządzących elit III RP.

Nie ma transformacji, która istniałaby poza dyskursem. Jest ta, o której się nam mówi, ta której logikę, cele i rezultaty nam się tłumaczy. W dyskursie IV RP została ona odmitologizowania i przedstawiona jako chybione przedsięwzięcie polityczne, przynoszące zyski nielicznym, zorganizowane przez ludzi o złych intencjach, uwikłanych w układy i zależnych od rządów obcych państw. To zaś, co dziś realizowane jest z użyciem hasła „dobrej zmiany”, przedstawiane jest jako konieczne, $w$ pewnym sensie bezalternatywne rozwiązanie, mające przywrócić „godność zwykłym Polakom”. Spór „rozgrywany” jest na płaszczyźnie symbolicznej i semantycznej — w tej sferze dąży się do legitymizacji władzy, a w zasadzie do uprawomocnienia własnej „dobrej opowieści” i delegitymizacji narracji, jaką posługiwali się oponenci. Strategie argumentacyjne prasy IV RP zmierzają do tego, aby dotychczasowe interpretacje zostały zawieszone, a pamięć instytucjonalna zmieniona. Zgromadzone w społeczeństwie dane i wiedza dotycząca polskiej transformacji i procesu demokratyzacji zostały poddane w prasie IV RP dekodowaniu i są zrekonstruowane jako nowa „dobra opowieść" $z$ na nowo rozpisanymi rolami aktorów politycznych, z nową dystrybucją odpowiedzialności i prestiżu.

Prasie IV RP i obozowi „dobrej zmiany” udało się stworzyć wspólnotę interpretacyjną, która stanowi dla tego środowiska silne zaplecze kulturowe i po- 
lityczne. Jak pisze Piotr Skwieciński (2018): „Rdzeń elektoratu PiS wierzy w tę partię dlatego, że uważa ją za wyraziciela własnych negatywnych emocji wobec elit III RP”. W ramach tej wspólnoty możliwe staje się tłumaczenie rzeczywistości przy użyciu gotowych pakietów interpretacyjnych (Horolets 2006, s. 22-26) opartych na macierzy wypracowanych strategii argumentacyjnych. Stworzono zasób symboliczny, który pełni rolę zbioru kategorii i definicji używanych do tłumaczenia tego, co się wydarzyło i pomagający w ocenie zmian, jakie zaszły w Polsce. Zmiana rządów w 2015 roku nie była więc zwykłym sukcesem partii politycznej, która wygrywa wybory i samodzielnie rządzi. W ramach dyskursu IV RP wydarzenie to należy odczytywać jako rezultat dziejowej sprawiedliwości, odzyskanie państwa przez tych, do których ono powinno należeć, przede wszystkim zaś jako przywrócenie zwierzchności władzy suwerena (tego pojęcia bardzo często używali politycy PiS w swoich medialnych komentarzach).

Obserwując wyniki ostatnich wyborów czy referendów w Stanach Zjednoczonych i w Europie (Francja, Wielka Brytania, Niemcy, Austria, Włochy) nie można stwierdzić, że istnieje pewien uniwersalny, czy choćby europejski, algorytm porządkujący elektoraty i pozwalający przewidzieć rozkład głosów. Istotne stają się lokalne modele kultur politycznych, w których ważną rolę odgrywają charakterystyczne dla danego państwa podziały. Coraz częściej mamy jednak do czynienia z rywalizacją między jakimś typem ugrupowania/kandydata konserwatywnego (mniej bądź bardziej nacjonalistycznego) z ugrupowaniem/kandydatem liberalnym (mniej bądź bardziej kosmopolitycznym). Kategorie te mogą pełnić jedynie rolę porządkujących etykiet służących mediom do sformułowania zrozumiałego dla odbiorców opisu kampanii wyborczej i przedstawiania jej jako pojedynku antagonistycznych wobec siebie aktorów politycznych, zajmujących konkurencyjne stanowiska ideologiczne.

Przeważnie ta rywalizacja rozgrywa się na poziomie języka, semantyki, retoryki, symboliki. Podział, którego źródła tkwią w określonych typach dyskursu staje się jednak jak najbardziej realny. Dyskurs IV RP odgrywa zasadniczą rolę $\mathrm{w}$ formowaniu się rozłamów społecznych. Tłumaczenie świata bazujące na narracji o przegranej transformacji trafiło do wielu grup społecznych, które je zaakceptowały i potraktowały jako wiarygodne (bądź przynajmniej jako lepsze od innych). I choćby było to tylko chwilowe uwiedzenie elektoratu, to konsekwencje zmian, jakie dokonały się później w systemie politycznym, będą długotrwałe - także pogłębiający się społeczny rozłam. Mimo że teza o dwóch antagonistycznych plemionach bywa krytykowana za upraszczający i zbyt trywialny charakter, ma ona pewien potencjał wyjaśniający i wpisuje się w binarną logikę sporów - w dyskurs polaryzacyjny. Retoryka dyskursu IV RP napotyka bowiem kontrretorykę, w ramach której inaczej definiowane są podstawowe problemy społeczne, fundamenty wspólnoty i demokratycznego państwa, autorytetom III RP wciąż okazywany jest szacunek, a władza PiS oceniana jest jako niedemokratyczna. 


\section{BIBLIOGRAFIA}

Alexander Jeffrey C., 2010, Znaczenia społeczne. Studia z socjologii kulturowej, tłum. Stanisław Burdziej, Jacek Gądecki, Nomos, Kraków.

Barker Chris, 2005, Studia kulturowe: teoria i praktyka, tłum. Agata Sadza, Wydawnictwo Uniwersytetu Jagiellońskiego, Kraków.

Burszta Wojciech, 2013, Kotwice pewności. Wojny kulturowe z popnacjonalizmem w tle, Iskry, Warszawa.

Cenckiewicz Stanisław, 2014, Raczkujacy przemyst pogardy, „Do Rzeczy”, nr 17.

Drogosz Marek, Bilewicz Michał, Kofta Mirosław, 2012, Poza stereotypy: dehumanizacja i esencjalizm w postrzeganiu grup społecznych, Scholar, Warszawa.

Drozda Łukasz, 2015, Lewactwo. Historia dyskursu o polskiej lewicy radykalnej, Instytut Wydawniczy Książka i Prasa, Warszawa.

Fedyszak-Radziejowska Barbara, 2014, O rocznicy Okragłego Stołu, „W Sieci”, nr 8.

Fish Stanley, 2002, Interpretacja, retoryka, polityka. Eseje wybrane, tłum. Krzysztof Abriszewski i in., Universitas, Kraków.

Gadowski Witold, 2013, Idzie burza, „W Sieci”, nr 11.

Hallin Daniel C., Mancini Paolo, 2004, Comparing Media Systems: Three Models of Media and Politics, Cambridge University Press, Cambridge-New York.

Horolets Anna, 2006, Obrazy Europy w polskim dyskursie publicznym, Universitas, Kraków.

Jakubowska-Branicka Iwona, 2013, O dogmatycznych narracjach: studium nienawiści, Wydawnictwo Trio, Warszawa.

Karnowski Michał, 2013, Im naprawdę żyje się lepiej, „W Sieci”, nr 37.

Krasnodębski Zdzisław, 2013, Zdrada solidarności, „W Sieci”, nr 36 .

Kurczewska Joanna, Cześnik Mikołaj, Pluciński Przemysław, Ścigaj Paweł, 2016, Dyskusja, „Władza Sądzenia. Krytyczni obywatele wobec demokracji w Polsce”, nr 10, s. 10-26.

Lasch Christopher, 1997, Bunt elit, tłum. Dobrosław Rodziewicz, Platan, Kraków.

Lipset Seymour M., 1995, Homo politicus. Spoteczne podstawy polityki, tłum. Grażyna Dziurdzik-Kraśniewska, Wydawnictwo Naukowe PWN, Warszawa.

Majmurek Jakub, 2013, III RP, czyli dwie cele wstydu, „Krytyka Polityczna”, nr 31-32.

Meisel James H., 1980, The Myth of the Ruling Class: Gaetano Mosca and the "Elite", Greenwood Press, Westport, Conn.

Messyasz Karolina, 2013, Obrazy młodzieży polskiej w dyskursie prasowym: młodzież o sobie i rzeczywistości społecznej, Wydawnictwo Uniwersytetu Łódzkiego, Łódź.

Müller Jan-Werner, 2017, Co to jest populizm?, tłum. Michał Sutowski, Wydawnictwo Krytyki Politycznej, Warszawa.

Nowicka Magdalena, 2014, Spory wokót książek Jana Tomasza Grossa w świetle postfoucaultowskiej analizy dyskursu, w: Marek Czyżewski, Karol Franczak, Magdalena Nowicka, Jerzy Stachowiak (red.), Dyskurs elit symbolicznych. Próba diagnozy, Wydawnictwo Akademickie Sedno, Warszawa.

Nykiel Marzena, 2013a, Awantura o zajęcia z gender, „W Sieci”, nr 26.

Nykiel Marzena, 2013b, Brunatne pióra, „W Sieci”, nr 41.

Nykiel Marzena, 2015, Polska $w$ turbanie, „W Sieci”, nr 37.

Pawlicki Maciej, 2012, Ilu nas jest?, „Uważam Rze”, nr 35.

Pawlicki Maciej, 2014, Dygot, „W Sieci”, nr 26.

Pawlicki Maciej, 2016, Wyspa hańby, „W Sieci”, nr 2.

Rybińska Aleksandra, 2016, Piekło Europy, „W Sieci”, nr7.

Rychard Andrzej, Sułek Antoni, 1988, Legitymacja. Klasyczne teorie i polskie doświadczenia, Polskie Towarzystwo Socjologiczne-Uniwersytet Warszawski, Warszawa.

Semka Piotr, 2013, Mały atlas wojujacych autorytetów, „Do Rzeczy”, nr 30.

Sieradzki Sławomir, 2014, Niemiecki kompleks Tuska, „W Sieci”, nr 17-18. 
Skwieciński Piotr, 2018, Kto się boi normalizacji, „Sieci”, nr 8.

Sloterdijk Peter, 2011, Gniew i czas. Esej polityczno-psychologiczny, tłum. Arkadiusz Żychliński, Scholar, Warszawa.

Szahaj Andrzej, 1997, Granice anarchizmu interpretacyjnego, „Teksty Drugie”, nr 6.

Śpiewak Paweł 2005, Pamięć po komunizmie, słowo obraz / terytoria, Gdańsk.

Terlikowski Tomasz, Terlikowska Małgorzata, 2013, Stop homoszkole, „Do Rzeczy”, nr 45.

van Dijk Teun A., 2001, Dyskurs jako struktura i proces: praca zbiorowa, tłum. Grzegorz Grochowski,

Teresa Dobrzyńska, Wydawnictwo Naukowe PWN, Warszawa.

van Dijk Teun A, 2006, Discourse, Context and Cognition, „Discourse Studies”, t. 8(1), s. 159-177.

Wasilewski Jacek, 2012, Opowieści o Polsce: retoryka narracji, studio headmade, Warszawa.

Wildstein Bronisław, 2012, Likwidacja „Uważam Rze”, „W Sieci”, nr 2.

Wildstein Bronisław, 2013, Polskość jako los, „Do Rzeczy”, nr 24.

Wildstein Bronisław, 2014. Kolorowa szara eminencja, „Do Rzeczy”, nr 16.

Wildstein Bronisław, 2016, Czy Europa chce popetnić samobójstwo?, „W Sieci”, nr 7.

Wildstein Bronisław, 2017, Znowu o Watęsie, „Sieci Prawdy”, nr 40.

Zaremba Piotr, 2014, Dotkliwa porażka mainstreamu, „W Sieci”, nr 26.

Ziemkiewicz Rafał A., 2013, Bunt młodych, „Do Rzeczy”, nr 44.

Ziemkiewicz Rafał A., 2014, Krytyka zjada Michnika, „Do Rzeczy”, nr 10.

Ziemkiewicz Rafał A., 2015a, Kwadratura imigracji, „Do Rzeczy”, nr 37.

Ziemkiewicz Rafał A., 2015b, To najeźdźcy, nie uchodźcy, „Do Rzeczy”, nr 38.

Zybertowicz Andrzej, 2013, Taniec na beczce z prochem, „W Sieci”, nr 34.

Zybertowicz Andrzej, 2014, Milcz, unikaj, kłam, „W Sieci”, nr 8.

\title{
NARRATIVES AND ARGUMENTATION STRATEGIES \\ IN THE DISCOURSE OF THE $4^{\text {th }}$ REPUBLIC AS AN INSTRUMENT FOR DEMARKING BORDERS IN POLISH SOCIETY
}

\author{
Marcin Kotras \\ (University of Łódź) \\ Summary
}

This article concerns discourse in the 4th Republic and its role in creating the divisions and cleavages of Polish society. The author analyzes the argumentation strategies used by the press supporting the government and its so-called "good change" (the weeklies Sieci and Uważam Rze, which were published in the years 2012-2017). He concentrates on selected rhetorical practices such as labeling, categorization, and discrimination, and determines that the center of the argumentation strategy of the weeklies analyzed is a discursively constructed division between the "elites" and the "masses" ("ordinary people"). This type of strategy allows the building of a Me-Them dichotomy, which serves not only to strengthen divisions but also to de-legitimize the social space of the $3^{\text {rd }}$ Republic and give legitimacy to the "good change" of the $4^{\text {th }}$ Republic. These activities are exemplified by the manner in which the writers in opinion-forming weeklies describe and explain selected topics and events, such as the Round Table Talks or the migration crisis. The author finds that in the argumentation strategies analyzed, the "nation" is understood as an exclusive community defined from an essentialist perspective. He relates these and other findings to the problem of the new, simplified form of political rivalry and contemporary election campaigns. 
Key words / słowa kluczowe

regime transformation / transformacja ustrojowa, narration / narracja, argumentation strategy / strategia argumentacyjna, social divisions / podziały społeczne, social cleavages / rozłamy społeczne, discourse of the $4^{\text {th }}$ Republic / dyskurs IV RP 